4

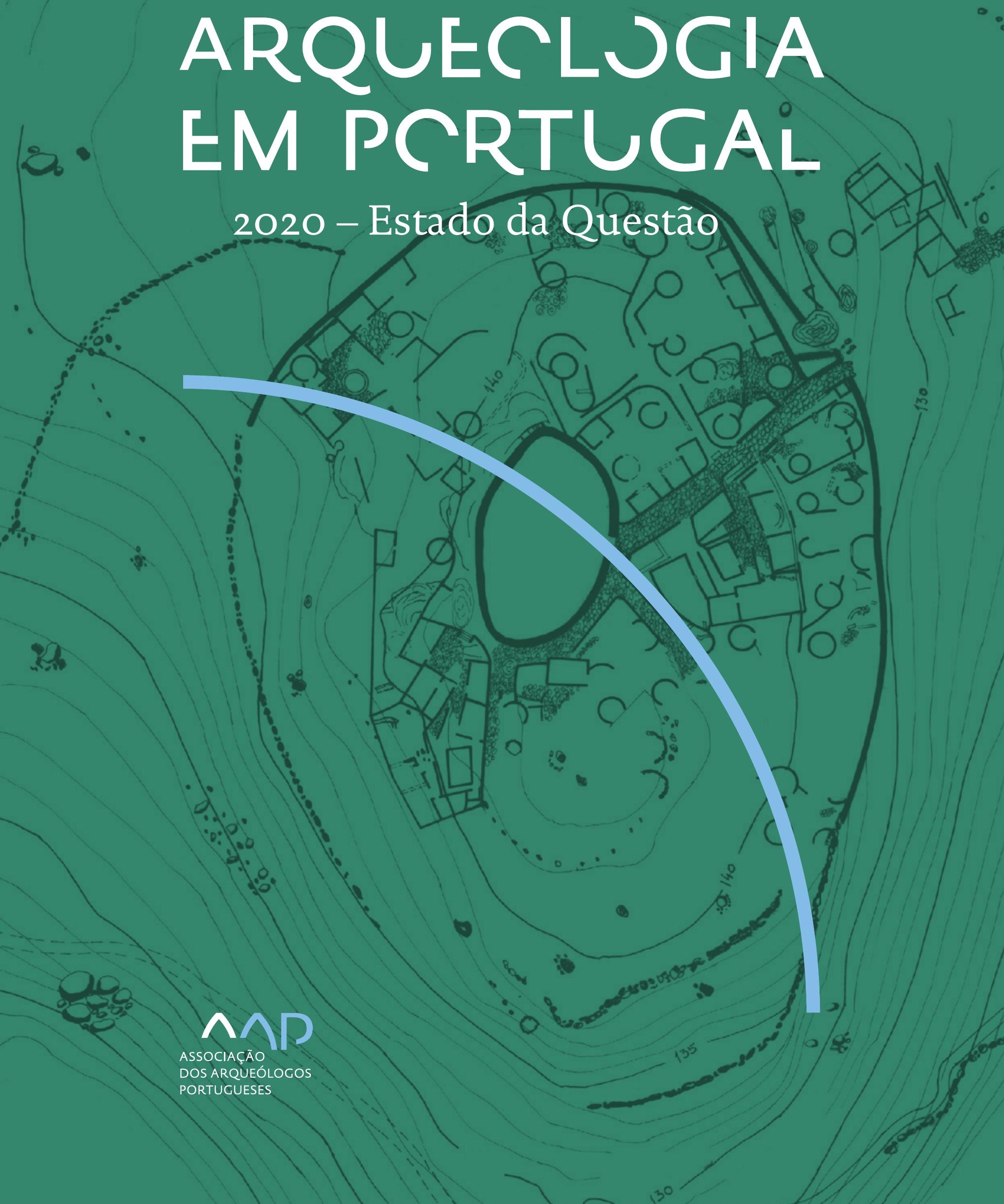


Coordenação editorial: José Morais Arnaud, César Neves e Andrea Martins Design gráfico: Flatland Design

AAP - ISBN: 978-972-9451-89-8

CITCEM - ISBN: 978-989-8970-25-1

Associação dos Arqueólogos Portugueses e CITCEM

Lisboa, 2020

O conteúdo dos artigos é da inteira responsabilidade dos autores. Sendo assim a Associação dos Arqueólogos Portugueses declina qualquer responsabilidade por eventuais equívocos ou questões de ordem ética e legal.

Desenho de capa:

Planta do castro de Monte Mozinho (Museu Municipal de Penafiel).

\section{$\hat{\wedge} \mathrm{P}$}

DOS ARQUEÓLOGOS PORTUGUESES

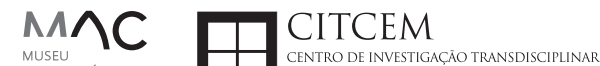
MUSEU
ARQUELLÓGICO
DO CARMO
U.PORTO

FLUP FACULDADE DE LETRAS
UNIVERSIDADE DO PORTO

Apoio

EC para a Ciência 


\section{Índice}

15 Prefácio

José Morais Arnaud

\section{Historiografia e Teoria}

17 Território, comunidade, memória e emoção: a contribuição da história da arqueologia (algumas primeiras e breves reflexões)

Ana Cristina Martins

25 Como descolonizar a arqueologia portuguesa?

Rui Gomes Coelho

41 Arqueologia e Modernidade: uma revisitação pessoal e breve de alguns aspetos da obra homónima de Julian Thomas de 2004

Vítor Oliveira Jorge

57 Dados para a História das Mulheres na Arqueologia portuguesa, dos finais do século XIX aos inícios do século XX: números, nomes e tabelas

Filipa Dimas / Mariana Diniz

73 Retractos da arqueologia portuguesa na imprensa: (in)visibilidades no feminino

Catarina Costeira / Elsa Luís

85 Arqueologia e Arqueólogos no Norte de Portugal Jacinta Bugalhão

101 Vieira Guimarães (1864-1939) e a arqueologia em Tomar: uma abordagem sobre o território e as gentes

João Amendoeira Peixoto / Ana Cristina Martins

115 Os memoráveis? A arqueologia algarvia na imprensa nacional e regional na presente centúria (2001-2019): características, visões do(s) passado(s) e a arqueologia

enquanto marca

Frederico Agosto / João Silva

129 A Evolução da Arqueologia Urbana e a Valorização Patrimonial no Barlavento Algarvio: Os casos de Portimão e Silves

Artur Mateus / Diogo Varandas / Rafael Boavida

\section{Gestão, Valorização e Salvaguarda do Património}

145 O Caderno Reivindicativo e as condições de trabalho em Arqueologia Miguel Rocha / Liliana Matias Carvalho / Regis Barbosa / Mauro Correia / Sara Simões / Jacinta Bugalhão / Sara Brito / Liliana Veríssimo Carvalho / Richard Peace / Pedro Peça / Cézer Santos

155 Os Estudos de Impacte Patrimonial como elemento para uma estratégia sustentável de minimização de impactes no âmbito de reconversões agrícolas Tiago do Pereiro

165 Salvaguarda de Património arqueológico em operações florestais: gestão e sensibilização Filipa Bragança / Gertrudes Zambujo / Sandra Lourenço / Belém Paiva / Carlos Banha / Frederico Tatá Regala / Helena Moura / Jacinta Bugalhão / João Marques / José Correia / Pedro Faria / Samuel Melro

179 Os valores do Património: uma investigação sobre os Sítios Pré-históricos de Arte Rupestre do Vale do Rio Côa e de Siega Verde José Paulo Francisco 
189 Conjugando recursos arqueológicos e naturais para potenciar as visitas ao Geoparque Litoral de Viana do Castelo (Noroeste de Portugal)

Hugo A. Sampaio / Ana M.S. Bettencourt / Susana Marinho / Ricardo Carvalhido

203 Áreas de Potencial Arqueológico na Região do Médio Tejo: Modelo Espacial Preditivo Rita Ferreira Anastácio / Ana Filipa Martins / Luiz Oosterbeek

223 Património Arqueológico e Gestão Territorial: O contributo da Arqueologia para a revisão do PDM de Avis

Ana Cristina Ribeiro

237 A coleção arqueológica do extinto Museu Municipal do Porto - Origens, Percursos e Estudos

Sónia Couto

251 Valpaços - uma nova carta arqueológica

Pedro Pereira / Maria de Fátima Casares Machado

263 Arqueologia na Cidade de Peniche

Adriano Constantino / Luís Rendeiro

273 Arqueologia Urbana: a cidade de Lagos como caso de Estudo Cátia Neto

285 Estratégias de promoção do património cultural subaquático nos Açores. O caso da ilha do Faial

José Luís Neto / José Bettencourt / Luís Borges / Pedro Parreira

297 Carta Arqueológica da Cidade Velha: Uma primeira abordagem

Jaylson Monteiro / Nireide Tavares / Sara da Veiga / Claudino Ramos / Edson Brito /

Carlos Carvalho / Francisco Moreira / Adalberto Tavares

311 Antropologia Virtual: novas metodologias para a análise morfológica e funcional Ricardo Miguel Godinho / Célia Gonçalves

\section{Didáctica da Arqueologia}

327 Como os projetos de Arqueologia podem contribuir para uma comunidade culturalmente mais consciente Alexandra Figueiredo / Claúdio Monteiro / Adolfo Silveira / Ricardo Lopes

337 Educação Patrimonial - Um cidadão esclarecido é um cidadão ativo! Ana Paula Almeida

351 A aproximação da Arqueologia à sala de aula: um caso de estudo no $3^{\circ}$ ciclo do Ensino Básico Luís Serrão Gil

363 Arqueologia 3.o - Pensar e comunicar a Arqueologia para um futuro sustentável Mónica Rolo

377 “Conversa de Arqueólogos" - Divulgar a Arqueologia em tempos de Pandemia Diogo Teixeira Dias

389 Escola Profissional de Arqueologia: desafios e oportunidades Susana Nunes / Dulcineia Pinto / Júlia Silva / Ana Mascarenhas

399 Os Museus de Arqueologia e os Jovens: a oferta educativa para o público adolescente Beatriz Correia Barata / Leonor Medeiros

411 O museu universitário como mediador entre a ciência e a sociedade: o exemplo da secção de arqueologia no Museu de História Natural e da Ciência da Universidade do Porto (MHNC-UP)

Rita Gaspar 
421 Museu de Lanifícios: Real Fábrica de Panos. Atividades no âmbito da Arqueologia Beatriz Correia Barata / Rita Salvado

427 Arqueologia Pública e o caso da localidade da Mata (Torres Novas) Cláudia Manso / Ana Rita Ferreira / Cristiana Ferreira / Vanessa Cardoso Antunes

431 Do sítio arqueológico ao museu: um percurso (também) didático Lídia Fernandes

447 Estão todos convidados para a Festa! E para dançar também... O projecto do Serviço Educativo do Museu Arqueológico do Carmo na $5^{\underline{a}}$ Edição da Festa da Arqueologia Rita Pires dos Santos

459 O “Clã de Carenque”, um projeto didático de arqueologia Eduardo Gonzalez Rocha

469 Mediação cultural: peixe que puxa carroça nas Ruínas Romanas de Troia Inês Vaz Pinto / Ana Patrícia Magalhães / Patrícia Brum / Filipa Santos

481 Didática Arqueológica, experiências do Projeto Mértola Vila Museu Maria de Fátima Palma / Clara Rodrigues / Susana Gómez / Lígia Rafael

\section{Arte Rupestre}

497 Os inventários de arte rupestre em Portugal Mila Simões de Abreu

513 O projeto FIRST-ART - conservação, documentação e gestão das primeiras manifestações de arte rupestre no Sudoeste da Península Ibérica: as grutas do Escoural e Maltravieso Sara Garcês / Hipólito Collado / José Julio García Arranz / Luiz Oosterbeek / António Carlos Silva / Pierluigi Rosina / Hugo Gomes / Anabela Borralheiro Pereira / George Nash / Esmeralda Gomes / Nelson Almeida / Carlos Carpetudo

523 Trabalhos de documentação de arte paleolítica realizados no âmbito do projeto PalæoCôa André Tomás Santos / António Fernando Barbosa / Luís Luís / Marcelo Silvestre / Thierry Aubry

537 Imagens fantasmagóricas, silhuetas elusivas: as figuras humanas na arte do Paleolítico Superior da região do Côa Mário Reis

$55^{1}$ Os motivos zoomórficos representados nas placas de tear de Vila Nova de São Pedro (Azambuja, Portugal) Andrea Martins / César Neves / José M. Arnaud / Mariana Diniz

571 Arte Rupestre do Monte de Góios (Lanhelas, Caminha). Síntese dos resultados dos trabalhos efectuados em 2007-2009 Mário Varela Gomes

599 Gravuras rupestres de barquiformes no Monte de S. Romão, Guimarães, Noroeste de Portugal Daniela Cardoso

613 Círculos segmentados gravados na Bacia do Rio Lima (Noroeste de Portugal): contributos para o seu estudo Diogo Marinho / Ana M.S. Bettencourt / Hugo Aluai Sampaio

631 Equídeos gravados no curso inferior do Rio Mouro, Monção (NW Portugal). Análise preliminar Coutinho, L.M. / Bettencourt, A.M.S / Sampaio, Hugo A.S

645 Paletas na Arte Rupestre do Noroeste de Portugal. Inventário preliminar Bruna Sousa Afonso / Ana M. S. Bettencourt / Hugo A. Sampaio 


\section{Pré-História}

661 O projeto Miño/Minho: balanço de quatro anos de trabalhos arqueológicos Sérgio Monteiro-Rodrigues / João Pedro Cunha-Ribeiro / Eduardo Méndez-Quintas / Carlos Ferreira / Pedro Xavier / José Meireles / Alberto Gomes / Manuel Santonja / Alfredo Pérez-González

677 A ocupação paleolítica da margem esquerda do Baixo Minho: a indústria lítica do sítio de Pedreiras 2 (Monção, Portugal) e a sua integração no contexto regional Carlos Ferreira / João Pedro Cunha-Ribeiro / Sérgio Monteiro-Rodrigues / Eduardo Méndez-Quintas / Pedro Xavier / José Meireles / Alberto Gomes / Manuel Santonja / Alfredo Pérez-González

693 O sítio acheulense do Plistocénico médio da Gruta da Aroeira Joan Daura / Montserrat Sanz / Filipa Rodrigues / Pedro Souto / João Zilhão

703 As sociedades neandertais no Barlavento algarvio: modelos preditivos com recurso aos SIG

Daniela Maio

715 A utilização de quartzo durante o Paleolítico Superior no território dos vales dos rios Vouga e Côa

Cristina Gameiro / Thierry Aubry / Bárbara Costa / Sérgio Gomes / Luís Luís / Carmen Manzano / André Tomás Santos

733 Uma perspetiva diacrónica da ocupação do concheiro do Cabeço da Amoreira (Muge, Portugal) a partir da tecnologia lítica Joana Belmiro / João Cascalheira / Célia Gonçalves

745 Novos dados sobre a Pré-história Antiga no concelho de Palmela. A intervenção arqueológica no sítio do Poceirão I

Michelle Teixeira Santos

757 Problemas em torno de Datas Absolutas Pré-Históricas no Norte do Alentejo Jorge de Oliveira

771 Povoamento pré-histórico nas áreas montanhosas do NO de Portugal: o Abrigo 1 de Vale de Cerdeira Pedro Xavier / José Meireles / Carlos Alves

783 Apreciação do povoamento do Neolítico Inicial na Baixa Bacia do Douro. A Lavra I (Serra da Aboboreira) como caso de estudo Maria de Jesus Sanches

797 O Processo de Neolitização na Plataforma do Mondego: os dados do Sector C do Outeiro dos Castelos de Beijós (Carregal do Sal)

João Carlos de Senna-Martinez / José Manuel Quintã Ventura / Andreia Carvalho / Cíntia Maurício

823 Novos trabalhos na Lapa da Bugalheira (Almonda, Torres Novas) Filipa Rodrigues / Pedro Souto / Artur Ferreira / Alexandre Varanda / Luís Gomes / Helena Gomes / João Zilhão

837 A pedra polida e afeiçoada do sítio do Neolítico médio da Moita do Ourives (Benavente, Portugal)

César Neves

857 Casal do Outeiro (Encarnação, Mafra): novos contributos para o conhecimento do povoamento do Neolítico final na Península de Lisboa.

Cátia Delicado / Carlos Maneira e Costa / Marta Miranda / Ana Catarina Sousa

873 Stresse infantil, morbilidade e mortalidade no sítio arqueológico do Neolítico Final/ Calcolítico ( $4^{\circ}$ e $3^{\circ}$ milénio a.C.) do Monte do Carrascal 2 (Ferreira do Alentejo, Beja) Liliana Matias de Carvalho / Sofia N. Wasterlain 
885 Come together: O Conjunto Megalítico das Motas (Monção, Viana do Castelo) e as expressões Campaniformes do Alto Minho Ana Catarina Basílio / Rui Ramos

899 Trabalhos arqueológicos no sítio Calcolítico da Pedreira do Poio Carla Magalhães / João Muralha / Mário Reis / António Batarda Fernandes

913 O sítio arqueológico de Castanheiro do Vento. Da arquitectura do sítio à arquitectura de um território João Muralha Cardoso

925 Estudo zooarqueológico das faunas do Calcolítico final de Vila Nova de São Pedro (Azambuja, Portugal): Campanhas de 2017 e 2018 Cleia Detry / Ana Catarina Francisco / Mariana Diniz / Andrea Martins / César Neves / José Morais Arnaud

943 As faunas depositadas no Museu Arqueológico do Carmo provenientes de Vila Nova de São Pedro (Azambuja): as campanhas de 1937 a 1967 Ana Catarina Francisco / Cleia Detry / César Neves / Andrea Martins / Mariana Diniz / José Morais Arnaud

959 Análise funcional de material lítico em sílex do castro de Vila Nova de S. Pedro (Azambuja, Portugal): uma primeira abordagem Rafael Lima

971 O recinto da Folha do Ouro 1 (Serpa) no contexto dos recintos de fossos calcolíticos alentejanos

António Carlos Valera / Tiago do Pereiro / Pedro Valério / António M. Monge Soares

\section{Proto-História}

987 Produção de sal marinho na Idade do Bronze do noroeste Português. Alguns dados para uma reflexão

Ana M. S. Bettencourt / Sara Luz / Nuno Oliveira / Pedro P. Simões / Maria Isabel C. Alves / Emílio Abad-Vidal

1001 A estátua-menir do Pedrão ou de São Bartolomeu do Mar (Esposende, noroeste de Portugal) no contexto arqueológico da fachada costeira de entre os rios Neiva e Cávado Ana M. S. Bettencourt / Manuel Santos-Estévez / Pedro Pimenta Simões / Luís Gonçalves

1015 O Castro do Muro (Vandoma/Baltar, Paredes) - notas para uma biografia de ocupação da Idade do Bronze à Idade Média

Maria Antónia D. Silva / Ana M. S. Bettencourt / António Manuel S. P. Silva / Natália Félix

1031 Do Bronze Final à Idade Média - continuidades e hiatos na ocupação de Povoados em Oliveira de Azeméis João Tiago Tavares / Adriaan de Man

1041 As faunas do final da Idade do Bronze no Sul de Portugal: leituras desde o Outeiro do Circo (Beja)

Nelson J. Almeida / Íris Dias / Cleia Detry / Eduardo Porfírio / Miguel Serra

1055 A Espada do Monte das Oliveiras (Serpa) - uma arma do Bronze Pleno do Sudoeste Rui M. G. Monge Soares / Pedro Valério / Mariana Nabais / António M. Monge Soares

1065 São Julião da Branca (Albergaria-a-Velha) - Investigação e valorização de um povoado do Bronze Final

António Manuel S. P. Silva / Paulo A. P. Lemos / Sara Almeida e Silva / Edite Martins de Sá

1083 Do castro de S. João ao Mosteiro de Santa Clara: notícia de uma intervenção arqueológica, em Vila do Conde Rui Pinheiro 
1095 O castro de Ovil (Espinho), um quarto de século de investigação - resultados e questões em aberto

Jorge Fernando Salvador / António Manuel S. P. Silva

1111 O Castro de Salreu (Estarreja), um povoado proto-histórico no litoral do Entre Douro e Vouga

Sara Almeida e Silva / António Manuel S. P. Silva / Paulo A. P. Lemos / Edite Martins de Sá

1127 Castro de Nossa Senhora das Necessidades (Sernancelhe): uma primeira análise artefactual Telma Susana O. Ribeiro

${ }_{1141}$ A cividade de Bagunte. O estado atual da investigação Pedro Brochado de Almeida

1153 Zoomorfos na cerâmica da Idade do Ferro no NW Peninsular: inventário, cronologias e significado Nuno Oliveira / Cristina Seoane

1163 Vasos gregos em Portugal: diferentes maneiras de contar a história do intercâmbio cultural na Idade do Ferro

Daniela Ferreira

1175 Os exotica da necrópole da Idade do Ferro do Olival do Senhor dos Mártires (Alcácer do Sal) no seu contexto regional

Francisco B. Gomes

\section{Antiguidade Clássica e Tardia}

1191 O uso de madeira como combustível no sítio da Quinta de Crestelos (Baixo Sabor): da Idade do Ferro à Romanização Filipe Vaz / João Tereso / Sérgio Simões Pereira / José Sastre / Javier Larrazabal Galarza / Susana Cosme / José António Pereira / Israel Espi

1207 Cultivos de Época Romana no Baixo Sabor: continuidade em tempos de mudança? João Pedro Tereso / Sérgio Simões Pereira / Filipe Santos / Luís Seabra / Filipe Vaz

1221 A casa romana na Hispânia: aplicação dos modelos itálicos nas províncias ibéricas Fernanda Magalhães / Diego Machado / Manuela Martins

1235 As pinturas murais romanas da Rua General Sousa Machado, n. ${ }^{5}$ 1, Chaves José Carvalho

1243 Trás do Castelo (Vale de Mir, Pegarinhos, Alijó) - Uma exploração agrícola romana do Douro

Tony Silvino / Pedro Pereira

1255 A sequência de ocupação no quadrante sudeste de Bracara Augusta: as transformações de uma unidade doméstica Lara Fernandes / Manuela Martins

1263 Os Mosaicos com decoração geométrica e geométrico-vegetalista dos sítios arqueológicos da área do Conuentus Bracaraugustanus. Novas abordagens quanto à conservação, restauro, decoração e datação Maria de Fátima Abraços / Licínia Wrench

1277 “Casa Romana” do Castro de São Domingos (Cristelos, Lousada): Escavação, Estudo e Musealização Paulo André de P. Lemos

1291 A arqueobotânica no Castro de Guifões (Matosinhos, Noroeste de Portugal): O primeiro estudo carpológico

Luís Seabra / Andreia Arezes / Catarina Magalhães / José Varela / João Pedro Tereso 
1305 Um Horreum Augustano na Foz do Douro (Monte do Castelo de Gaia, Vila Nova de Gaia) Rui Ramos

1311 Ponderais romanos na Lusitânia: padrões, formas, materiais e contextos de utilização Diego Barrios Rodríguez

1323 Um almofariz centro-itálico na foz do Mondego

Marco Penajoia

1335 Estruturas romanas de Carnide - Lisboa Luísa Batalha / Mário Monteiro / Guilherme Cardoso

1347 O contexto funerário do sector da "necrópole NO" da Rua das Portas de S. Antão (Lisboa): o espaço, os artefactos, os indivíduos e a sua interconectividade na interpretação do passado Sílvia Loja, José Carlos Quaresma, Nelson Cabaço, Marina Lourenço, Sílvia Casimiro, Rodrigo Banha da Silva, Francisca Alves-Cardoso

${ }_{1361}$ Povoamento em época Romana na Amadora - resultados de um projeto pluridisciplinar Gisela Encarnação / Vanessa Dias

1371 A Arquitectura Residencial em Mirobriga (Santiago do Cacém): contributo a partir de um estudo de caso Filipe Sousa / Catarina Felício

${ }_{1385}$ O fim do ciclo. Saneamento e gestão de resíduos nos edifícios termais de Mirobriga (Santiago do Cacém)

Catarina Felício / Filipe Sousa

1399 Balsa, Topografia e Urbanismo de uma Cidade Portuária Vítor Silva Dias / João Pedro Bernardes / Celso Candeias / Cristina Tété Garcia

1413 No Largo das Mouras Velhas em Faro (2017): novas evidências da necrópole norte de Ossonoba e da sua ocupação medieval Ricardo Costeira da Silva / Paulo Botelho / Fernando Santos / Liliana Nunes

1429 Instrumentos de pesca recuperados numa fábrica de salga em Ossonoba (Faro) Inês Rasteiro / Ricardo Costeira da Silva / Paulo Botelho

1439 A Necrópole Romana do Eirô, Duas Igrejas (Penafiel): intervenção arqueológica de 2016 Laura Sousa / Teresa Soeiro

1457 Ritual, descarte ou afetividade? A presença de Canis lupus familiaris na Necrópole Noroeste de Olisipo (Lisboa)

Beatriz Calapez Santos / Sofia Simões Pereira / Rodrigo Banha da Silva / Sílvia Casimiro / Cleia Detry / Francisca Alves Cardoso

1467 Dinâmicas económicas em Bracara na Antiguidade Tardia Diego Machado / Manuela Martins / Fernanda Magalhães / Natália Botica

1479 Cerâmicas e Vidros da Antiguidade Tardia do Edifício sob a Igreja do Bom Jesus (Vila Nova de Gaia) Joaquim Filipe Ramos

1493 Novos contributos para a topografia histórica de Mértola no período romano e na Antiguidade Tardia Virgílio Lopes

\section{8. Época Medieval}

1511 Cerâmicas islâmicas no Garb setentrional "português": algumas evidências e incógnitas Constança dos Santos / Helena Catarino / Susana Gómez / Maria José Gonçalves / Isabel Inácio / Gonçalo Lopes / Jacinta Bugalhão / Sandra Cavaco / Jaquelina Covaneiro / Isabel Cristina Fernandes / Ana Sofia Gomes 
1525 Contributo para o conhecimento da cosmética islâmica, em Silves, durante a Idade Média Rosa Varela Gomes

1537 Yábura e o seu território - uma análise histórico-arqueológica de Évora entre os séculos VIII-XII José Rui Santos

1547 A encosta sul do Castelo de Palmela - resultados preliminares da escavação arqueológica Luís Filipe Pereira / Michelle Teixeira Santos

1559 A igreja de São Lourenço (Mouraria, Lisboa): um conjunto de silos e de cerâmica medieval islâmica

Andreia Filipa Moreira Rodrigues

1571 O registo material de movimentações populacionais no Médio Tejo, durante os séculos XII-XIII. Dois casos de "sunken featured buildings", nos concelhos de Cartaxo e Torres Novas Marco Liberato / Helena Santos / Nuno Santos

1585 O nordeste transmontano nos alvores da Idade média. Notas para reflexão Ana Maria da Costa Oliveira

1601 Sepulturas escavadas na rocha do Norte de Portugal e do Vale do Douro: primeiros resultados do Projecto SER-NPVD

Mário Jorge Barroca / César Guedes / Andreia Arezes / Ana Maria Oliveira

1619 "Portucalem Castrum Novum" entre o Mediterrâneo e o Atlântico: o estudo dos materiais cerâmicos alto-medievais do arqueossítio da rua de D. Hugo, nํ. 5 (Porto) João Luís Veloso

1627 A Alta Idade Média na fronteira de Lafões: notas preliminares sobre a Arqueologia no Concelho de Vouzela

Manuel Luís Real / Catarina Tente

1641 Um conjunto cerâmico medieval fora de portas: um breve testemunho aveirense Susana Temudo

${ }_{1651}$ Os Lóios do Porto: uma perspetiva integrada no panorama funerário da Baixa Idade Média à Época Moderna em meios urbanos em Portugal

Ana Lema Seabra

1659 O Caminho Português Interior de Santiago como eixo viário na Idade Média Pedro Azevedo

1665 Morfologia Urbana: Um exercício em torno do Castelo de Ourém André Donas-Botto / Jaqueline Pereira

1677 Intervenção arqueológica na Rua Marquês de Pombal/Largo do Espírito Santo (Bucelas, Loures)

Florbela Estêvão / Nathalie Antunes-Ferreira / Dário Ramos Neves / Inês Lisboa

1691 O Cemitério Medieval do Poço do Borratém e a espacialidade funerária na cidade de Lisboa Inês Belém / Vanessa Filipe / Vasco Noronha Vieira / Sónia Ferro / Rodrigo Banha da Silva

1705 Um Espaço Funerário Conventual do séc. XV em Lisboa: o caso do Convento de São Domingos da Cidade Sérgio Pedroso / Sílvia Casimiro / Rodrigo Banha da Silva / Francisca Alves Cardoso

\section{9. Época Moderna e Contemporânea}

1721 Arqueologia Moderna em Portugal: algumas reflexões críticas em torno da quantificação de conjuntos cerâmicos e suas inferências históricas e antropológicas Rodrigo Banha da Silva / André Bargão / Sara da Cruz Ferreira

1733 Faianças de dois contextos entre os finais do século XVI e XVIII do Palácio dos Condes de Penafiel, Lisboa

Martim Lopes / Tomás Mesquita 
1747 Um perfil de consumo do século XVIII na foz do Tejo: O caso do Mercado da Ribeira, Lisboa Sara da Cruz Ferreira / Rodrigo Banha da Silva / André Bargão

1761 Os Cachimbos dos Séculos XVII e XVIII do Palácio Mesquitela e Convento dos Inglesinhos (Lisboa)

Inês Simão / Marina Pinto / João Pimenta / Sara da Cruz Ferreira / André Bargão / Rodrigo Banha da Silva

1775 "Tomar os fumos da erua que chamão em Portugal erua sancta». Estudo de Cachimbos provenientes da Rua do Terreiro do Trigo, Lisboa

Miguel Martins de Sousa / José Pedro Henriques / Vanessa Galiza Filipe

1787 Cachimbos de Barro Caulínitico da Sé da Cidade Velha (República de Cabo Verde)

Rodrigo Banha da Silva / João Pimenta / Clementino Amaro

1801 Algumas considerações sobre espólio não cerâmico recuperado no Largo de Jesus (Lisboa) Carlos Boavida

1815 Adereços de vidro, dos séculos XVI-XVIII, procedentes do antigo Convento de Santana de Lisboa (anéis, braceletes e contas)

Joana Gonçalves / Rosa Varela Gomes / Mário Varela Gomes

1837 Da ostentação, luxo e poder à simplicidade do uso quotidiano: arqueologia e simbologia de joias e adornos da Idade Moderna Portuguesa Jéssica Iglésias

1849 Os amuletos em Portugal - dos objetos às superstições: o coral vermelho Alexandra Vieira

1865 Cerâmicas de Vila Franca de Xira nos séculos XV e XVI Eva Pires

1879 «Não passa por teu o que me pertence». Marcas de individualização associadas a faianças do Convento de Nossa Senhora de Aracoeli, Alcácer do Sal Catarina Parreira / Íris Fragoso / Miguel Martins de Sousa

1891 Cerâmica de Leiria: alguns focos de produção

Jaqueline Pereira / André Donas-Botto

1901 Os Fornos na Rua da Biquinha, em Óbidos Hugo Silva / Filipe Oliveira

1909 A casa de Pêro Fernandes, contador dos contos de D. Manuel I: o sítio arqueológico da Silha do Alferes, Seixal (século XVI) Mariana Nunes Ferreira

1921 O Alto da Vigia (Sintra) e a vigilância e defesa da costa Alexandre Gonçalves / Sandra Santos

1937 O contexto da torre sineira da Igreja de Santa Maria de Loures Paulo Calaveira / Martim Lopes

1949 A Necrópole do Hospital Militar do Castelo de São Jorge e as práticas funerárias na Lisboa de Época Moderna Susana Henriques / Liliana Matias de Carvalho / Ana Amarante / Sofia N. Wasterlain

1963 SAND - Sarilhos Grandes Entre dois Mundos: o adro da Igreja e a Paleobiologia dos ossos humanos recuperados

Paula Alves Pereira / Roger Lee Jesus / Bruno M. Magalhães

1975 Expansão urbana da vila de Cascais no século XVII e XVIII: a intervenção arqueológica na Rua da Vitória no 15 a 17

Tiago Pereira / Vanessa Filipe

1987 Novos dados para o conhecimento do Urbanismo de Faro em época Moderna Ana Rosa 
1995 Um exemplo de Arqueologia Urbana em Alcoutim: o Antigo Edifício dos CTT Marco Fernandes / Marta Dias / Alexandra Gradim / Virgílio Lopes / Susana Gómez Martínez

2007 Palácio dos Ferrazes (Rua das Flores/Rua da Vitória, Porto): a cocheira de Domingos Oliveira Maia

Francisco Raimundo

2021 As muitas vidas de um edifício urbano: História, Arqueologia e Antropologia no antigo Recreatório Paroquial de Penafiel Helena Bernardo / Jorge Sampaio / Marta Borges

2035 O convento de Nossa Senhora da Esperança de Ponta Delgada: o contributo da arqueologia para o conhecimento de um monumento identitário João Gonçalves Araújo / N’Zinga Oliveira

2047 Arqueologia na ilha do Corvo... em busca da capela de Nossa Senhora do Rosário Tânia Manuel Casimiro / José Luís Neto / Luís Borges / Pedro Parreira

2059 Perdidos à vista da Costa. Trabalhos arqueológicos subaquáticos na Barra do Tejo Jorge Freire / José Bettencourt / Augusto Salgado

2071 Arqueologia marítima em Cabo Verde: enquadramento e primeiros resultados do projecto CONCHA

José Bettencourt / Adilson Dias / Carlos Lima / Christelle Chouzenoux / Cristóvão Fonseca / Dúnia Pereira / Gonçalo Lopes / Inês Coelho / Jaylson Monteiro / José Lima / Maria Eugénia Alves / Patrícia Carvalho / Tiago Silva

2085 Trabalhos arqueológicos na Cidade Velha (Ribeira Grande de Santiago, Cabo Verde): reflexões sobre um projecto de investigação e divulgação patrimonial André Teixeira / Jaylson Monteiro / Mariana Mateus / Nireide Tavares / Cristovão Fonseca / Gonçalo C. Lopes / Joana Bento Torres / Dúnia Pereira / André Bargão / Aurélie Mayer / Bruno Zélie / Carlos Lima / Christelle Chouzenoux / Inês Henriques / Inês Pinto Coelho / José Lima / Patrícia Carvalho / Tiago Silva

2103 A antiga fortificação de Quelba / Khor Kalba (E.A.U.). Resultados de quatro campanhas de escavações, problemáticas e perspectivas futuras Rui Carita / Rosa Varela Gomes / Mário Varela Gomes / Kamyar Kamyad

2123 Colónias para homens novos: arqueologia da colonização agrária fascista no noroeste ibérico Xurxo Ayán Vila / José Mạ . Señorán Martín 


\title{
ESCOLA PROFISSIONAL \\ DE ARQUEOLOGIA: DESAFIOS E OPORTUNIDADES
}

\author{
Susana Nunes ${ }^{1}$, Dulcineia Pinto ${ }^{2}$, Júlia Silva ${ }^{3}$, Ana Mascarenhas ${ }^{4}$
}

\begin{abstract}
RESUMO
O desafio permanente da educação, e do ensino profissional em particular, exige uma permanente adaptação das práticas pedagógicas ao mundo global em que vivemos. As gerações mais novas fazem emergir a necessidade de estratégias que tornem as práticas pedagógicas mais motivadoras e adequadas a um mundo em constante mudança.

Em resposta a este desafio, a Escola Profissional de Arqueologia (EPA) tem vindo a desenvolver projetos e atividades, que permitem, por um lado, dotar os nossos alunos das competências técnicas específicas da área da arqueologia; e por outro, divulgar e fomentar o gosto e respeito pelo património cultural, particularmente arqueológico.
\end{abstract}

Palavras-chave: Ensino profissional, Arqueologia, Aprendizagem, Práticas pedagógicas, Projetos.

\begin{abstract}
The permanent challenge of education in general, and vocational education in particular, requires a permanent adaptation of pedagogical practices to the global world in which we live. The younger generations raise the need for strategies that make pedagogical practices more motivating and appropriate to a world in constant change. In response to this challenge, the Professional School of Archeology (EPA) has been developing projects and activities that allow, on the one hand, to equip our students with specific technical skills in the area of archeology; and on the other hand, to disseminate and promote the taste and respect for cultural heritage, particularly archaeological.
\end{abstract}

Keywords: Vocational education, Archeology, Learning, Pedagogical practices, Projects.

\section{INTRODUÇÃO}

A Escola Profissional de Arqueologia (EPA) é uma instituição pública de ensino profissional dedicada à área do Património Cultural, implantada na aldeia de Santa Maria do Freixo, em plena Área Arqueológica do Freixo, espaço de cerca de 50 hectares classificado como Monumento Nacional - a cidade romana de Tongobriga (Figura 1).

A sua criação surge associada ao aumento do mercado de trabalho na área da Arqueologia, nas décadas de 80 e 90 do séc. XX, com a necessidade de cria-

\footnotetext{
1. Escola profissional de Arqueologia; susananunes@epa.pt

2. Escola profissional de Arqueologia; dulcineiapinto@epa.pt

3. Escola profissional de Arqueologia; juliasilva@epa.pt

4. Escola profissional de Arqueologia; anamascarenhas@epa.pt
}

ção de um corpo profissional de arqueólogos capaz de responder de forma competente aos normativos legais e às crescentes solicitações que o desenvolvimento urbanístico e as obras públicas acarretavam. A Escola Profissional de Arqueologia é então criada em 1990, através de um contrato-programa celebrado entre o Gabinete de Educação Tecnológica, Artística e Profissional e o Instituto Português do Património Arquitetónico e Arqueológico, em representação, respetivamente do Ministério da Educação e Ministério da Cultura, propondo-se a formar um corpo de técnicos em arqueologia capazes de 
apoiar os arqueólogos formados pelas universidades. Com a promulgação da Portaria no ${ }^{\circ}$ 795/200o, de 20 de setembro, a escola é integrada na rede pública de estabelecimentos de ensino, sendo o seu financiamento assegurado em partes iguais pelos Ministérios da Educação e da Cultura.

O primeiro curso a avançar foi o de Assistente de Arqueólogo, seguindo-se o Curso de Técnico de Museografia e Divulgação do Património e o de Assistente de Conservação e Restauro. Mais recentemente a Escola apostou no curso de Técnico de Recuperação do Património Edificado, em resposta às necessidades identificadas no mercado. Na implantação dos cursos vocacionais, em 2015 inicia-se o curso de Técnico Operacional do Património e Turismo para o $3^{\circ}$ ciclo. No ano letivo de 2016-2017 inicia-se o curso de educação e formação (CEF) de Operador de Fotografia, também para o $3^{\circ}$ ciclo e em 2018 e 2019 os cursos de Técnico de Animação em Turismo e Técnico de Fotografia, respetivamente.

\section{A FORMAÇÃO TECNOLÓGICA DO ASSISTENTE DE ARQUEÓLOGO}

O Assistente de Arqueólogo éo técnico que, sob a supervisão do Arqueólogo, executa "ações conducentes à investigação, registo, análise e conservação de sítios e materiais arqueológicos, através da utilização de equipamentos e aplicação de técnicas necessárias para a execução de trabalhos de escavação, prospeção, topografia, cartografia, desenho, fotografia, conservação e restauro de bens arqueológicos (Catálogo Nacional de Qualificações, Referencial de Formação, código 225021) (Figura 3). Além disto, dele se espera que participe em atividades de estudo, conservação e valorização do Património Arqueológico

Os Cursos Profissionais destinam-se a formandos com o $9^{\circ}$ ano de escolaridade ou formação equivalente, que valoriza o desenvolvimento de competências para o exercício de uma profissão, sendo um ensino mais prático e voltado para o mundo do trabalho, com duração de 3 anos, conferem dupla certificação: Diploma de Certificação Profissional de nível 4 de acordo com o Quadro Nacional de Qualificação (QNQ) e Quadro Europeu de Qualificações (QEQ), reconhecido em todos os Estados Membros (Portaria no 782/2009) e Diploma do Ensino Secundário com equivalência ao $12^{\circ}$ ano de escolaridade com possibilidade de acesso ao ensino superior.
No ensino profissional a "formação é organizada em módulos, unidades significativas de aprendizagem de natureza e duração variáveis, que se combinam entre si formando uma Estrutura Modular. Esta organização permite integrar formandos com níveis de formação e características muito diferenciadas e responde, entre outros, a três pressupostos subjacentes à criação destas escolas: (i) orientação educativa diferenciada; (ii) apoio personalizado; (iii) significado formativo da avaliação."

O Curso de Assistente de Arqueólogo inclui-se na área de Formação de História e Arqueologia (225), e é um curso profissional durante o qual os formandos aprendem a recolher, registar, tratar, analisar e conservar sítios e materiais arqueológicos, através da utilização de equipamentos e aplicação de técnicas apropriadas.

Os formandos têm aulas de disciplinas da componente geral, científica e da componente técnica, intercalados com períodos de Formação em Contexto de Trabalho (FCT) (ver tabela com Plano Curricular). Assim, para além de disciplinas da Componente Sócio Cultural - Português, Inglês, Área de Integração, Técnicas de Informação e Comunicação e Educação Física, os alunos têm disciplinas da componente científica, a fixar em regulamentação própria, em função das qualificações profissionais a adquirir (ANQEP), designadamente Matemática, História e Cultura das Artes e Físico-Química. A grande maioria das horas de formação correspondem a módulos da componente tecnológica e a períodos de FCT. A componente tecnológica inclui disciplinas de natureza tecnológica, técnica e prática estruturantes da qualificação profissional visada conforme referido pela ANQEP. No caso do curso de Assistente de Arqueólogo, esta pode ser dividida em três áreas: Técnicas de Investigação em Arqueologia ${ }^{5}$, Técnicas de

5. * UFCD: 4077. Técnicas de investigação arqueológica; 4078. Cultura material em arqueologia; 4079. Contextos específicos em arqueologia; 408o. Instrumentos e metodologias de trabalho em arqueologia; 4081. Métodos e técnicas de prospeção arqueológica; 4082. Trabalho de campo em prospeção arqueológica; 4083. Estratigrafia arqueológica; 4084. Cartografia arqueológica; 4085. Análise de materiais arqueológicos; 4086. Análise de estruturas arqueológicas; 4087. Legislação em arqueologia e património; 4088. Atividades complementares na investigação arqueológica; 4089. Projeto de investigação em arqueologia. 
Registo em Arqueologia ${ }^{6}$ e Técnicas de Conservação em Arqueologia 7 .

A Formação em Contexto de Trabalho "visa a aquisição e o desenvolvimento de competências técnicas, relacionais e organizacionais relevantes para a qualificação profissional a adquirir" (ANQEP), proporcionando ao formando períodos de aprendizagem mais próximos do que será o contexto de trabalho real. Na EPA estes períodos decorrem ao longo dos três anos, de forma a que possam ter uma experiência mais diversificada. Normalmente o primeiro período de FCT é realizado na escola, mas os restantes são preferencialmente realizados externamente, sob a forma de participação em trabalhos arqueológicos (escavações, prospeções, tratamento de material, entre outros), e têm a duração de uma semana a um mês (em setembro, na Páscoa e em junho/ julho).

No final do curso o aluno tem de apresentar um projeto, designado por Prova de Aptidão Profissional (PAP), onde demonstra as competências e conhecimentos que desenvolveu ao longo da formação.

As aulas decorrem nas instalações da EPA, em casas de habitação adaptadas a salas de aula, nas ruínas, no gabinete da Área Arqueológica e no centro interpretativo.

6. UFCD: 409o. Técnicas de inventário de património cultural; 4091. Técnicas de registo em arte rupestre; 4092. Desenho de estruturas arqueológicas; 4093. Desenho de estratigrafia arqueológica; 4094. Desenho arqueológico de edifícios; 4095. Desenho arqueológico de materiais cerâmicos; 4096. Desenho arqueológico de objetos; 4097. Desenho arqueológico de materiais líticos; 4098. Tratamento gráfico de desenho arqueológico; 4099. SIG 'S Arqueologia; 410o.Matemática aplicada à topografia; 4101. Técnicas de registo em cartografia arqueológica; 4102. Métodos e técnicas de levantamentos topográficos; 4103. Trabalho de campo em topografia arqueológica; 4104. Fotografia; 4105. Fotografia arqueológica.

7. UFCD: 4106. Conservação preventiva; 4107. Técnicas de registo e diagnóstico; 4108. Técnicas de limpeza e manutenção; 4109. Ambientes e técnicas de estabilização; 4110. Técnicas de conservação in situ; 4111. Técnicas de restauro em arqueologia; 4112. Técnicas de conservação em ruínas arqueológicas; 4113. Técnicas de conservação de rochas e argamassas; 4114. Técnicas de conservação de cerâmica e vidro; 4115. Técnicas de conservação de metais e ligas; 4116. Técnicas de conservação de mosaico e pintura mural; 4117. Técnicas de conservação de materiais orgânicos; 0349. Ambiente, segurança, higiene e saúde no Trabalho.

\section{OS PROJETOS E ATIVIDADES COMO FORMAS DE APRENDIZAGEM SIGNIFICATIVAS}

A articulação entre as várias disciplinas, em especial entre as da Componente Técnica, foi sempre comum na EPA, uma vez que o próprio trabalho em Arqueologia (como na Museografia e na Conservação e Restauro) é, necessariamente, interdisciplinar e colaborativo.

Atualmente a EPA desenvolve uma série de projetos, de que destacamos o Projeto Museus pelo Mundo, Arqueopólio e Olimpíadas da Antiguidade.

O fato de estes dois últimos projetos terem iniciado no ano letivo de 2016-2017 mostra bem o trabalho que vem ser desenvolvido na EPA, numa lógica da Aprendizagem Baseada em Projetos, onde se procura a articulação entre as diferentes componentes dos cursos e uma maior ligação dos alunos à escola, a partir da adesão a um projeto comum a que os próprios deram forma desde a conceção à apresentação final e disseminação.

Desde o ano letivo 2015-2016 que a EPA realiza as Oficinas de Educação Patrimonial, com o objetivo de incrementar a defesa, gosto e respeito pelo património cultural, particularmente o arqueológico, objetivos para o qual contribuiu também a exposição intitulada "Arqueologia. Ciência que estuda o passado”, concebida no ano letivo 2016-2017 (e que vai já na sua quarta edição).

O Arqueopólio é um jogo de tabuleiro criado para dar a conhecer o Património Cultural Português com uma configuração baseada no Monopólio (Figura 4). Este projeto interdisciplinar foi desenvolvido em contexto de sala de aula, numa lógica da aprendizagem por projetos. O objetivo era transmitir, de forma motivadora, os conteúdos programáticos de disciplinas dos cursos profissionais de AA e TMGP, nomeadamente a classificação do património cultural português e os vários tipos de sítios arqueológicos, temas abordados no $1^{\circ}$ ano desses cursos.

Assim em sala de aula, foram desenvolvidas as seguintes tarefas: 1) levantamento do património arqueológico classificado português; (2) seleção dos sítios a constar no jogo e recolha de fotografias representativas; (3) organização do "Layout" do tabuleiro; (4) vetorização dos vários ícones (categorias, cartas, serviços e peões); (5) criação das notas e cartões de concessão de espaços.

Daqui resultou o Arqueopólio, um jogo de tabuleiro 
cujo objetivo é fazer a gestão do Património Cultural Português através da concessão/ exploração de bens patrimoniais.

O projeto foi criado no âmbito da participação na $14^{\underline{a}}$ edição do prémio Fundação Ilídio Pinho - Ciência na Escola 2016-2017, tendo sido um dos 100 finalistas.

O projeto foi concebido segundo a lógica da interdisciplinaridade e transdisciplinaridade.

O Projeto Museus pelo Mundo é um projeto de divulgação de património cultural inserido noProjeto de Autonomia e Flexibilidade Curricular. Com este projeto pretende-se angariar o maior número possível de postais de museus por forma a constituir uma coleção de postais de todo o mundo (Figura 5).

Até ao momento recebemos mais de 700 postais de países de todo o mundo; temos escolas e professores interessados em trabalhar o projeto e temos dois museus a trabalharem no projeto.

Numa primeira etapa transformou-se uma sala de aula (laboratório) numa sala de exposição do projeto, onde os postais são acondicionados e expostos. Este espaço pode ser visitável e receber grupos, que podem vir aqui conhecer o projeto e realizar atividades programadas.

A médio e longo prazo coleção está a ser trabalhada, através do seu registo sob a forma de inventário e fotografia, em várias disciplinas: Comunicação Visual, Património, Divulgação de Património, Inglês. A mais valia deste projeto é serem os postais instrumentos/meios pedagógicos para se atingirem as aprendizagens essenciais.

No dia 1o de maio de 2017, a Escola Profissional de Arqueologia organizou as primeiras Olimpíadas da Antiguidade, tendo sido adiadas as quartas Olimpíadas para 2021 devido ao COVID. As Olimpíadas da Antiguidade da EPA realizam-se no Fórum romano de Tongobriga, e incluem as seguintes modalidades:

- stadio - prova de corrida de velocidade com o comprimento do Fórum de Tongobriga (cerca de $60 \mathrm{~m})$;

- lampadedromía - prova de corrida de estafetas (4X6om), constituída por quatro atletas, semelhante à corrida de estafetas atual. O desafio é correr com uma tocha acesa e passá-la ao companheiro de equipa sem que ela se apague;

- dískos - prova de lançamento de um disco de metal à maior distância possível.

-ákon - prova de lançamento de um dardo de forma a atingir a maior distância possível.
- pédema - prova de salto, com os pés juntos, sem correr e com pesos nas mãos, de forma a atingir a maior distância possível.

Para além das provas físicas estas Olimpíadas integraram também um torneio de jogos de tabuleiro romanos-Centurium (C).

Desde o ano letivo 2015-2016 que a EPA integra de forma sistemática na sua missão, a divulgação do património cultural. Esta divulgação, que começou com a realização de oficinas pedagógicas e palestras direcionadas sobretudo para a arqueologia, tem vindo a reinventar-se ao longo do tempo, apostando em novos formatos e abrangendo outras áreas do património cultural.

As atividades com mais sucesso são a Oficina de Mosaicos e a Simulação de escavação arqueológica.

Na primeira, os participantes recriam a técnica romana do mosaico. Estas sessões são dirigidas aos alunos entre os 10-15 anos, com a duração de 45 a 90 mins. Com base nas técnicas, materiais, motivos e organização das composições geométricas, são abordadas questões relacionadas com a vida doméstica e quotidiana romana. Alguns dos motivos baseiam-se, também, no pavimento em mosaico datado do século V-VI d.C., identificado na igreja de Santa Maria do Freixo, mesmo em frente à Escola Profissional de Arqueologia.

Uma das primeiras atividades desenvolvidas e que mais sucesso tem é a denominada Arqueólogo por um dia, que se constitui comum uma simulação de escavação arqueológica. (Figura 6) Em áreas de escavação portáteis são recriados contextos arqueológicos de diferentes épocas, de modo a permitir reconstituir as ações das pessoas do passado. Consiste numa oficina prática com introdução ao trabalho próprio do arqueólogo e à prática simulada de todos os procedimentos inerentes à escavação arqueológica, tratamento preliminar de espólio arqueológico e interpretação de resultados. De acordo com cada problema, cabe aos alunos, interagindo com os investigadores, a utilização de todos os recursos disponíveis com vista à apresentação de hipóteses explicativas. As atividades são avaliadas através da discussão entre pares e com os orientadores da atividade. Com esta oficina pretende-se que os participantes compreendam a importância da escavação arqueológica para a construção do conhecimento e apliquem os princípios do método científico na recolha, classificação e análise dos dados arqueológicos, desenvol- 
vendo competências de iniciativa, planificação, execução e interpretação. Destinadas a crianças e jovens dos 4-15 anos e com uma duração entre 45 a 90 mins, são antecedidas de uma apresentação de introdução à arqueologia e ao trabalho do arqueólogo.

Esta prática simulada de escavação arqueológica é um meio utilizado em duas abordagens distintas, quanto ao rigor e aprendizagens:

- uma enquanto estratégia de aprendizagem aplicada aos alunos que iniciam o curso de assistente de arqueólogo, em que o objetivo principal é a introdução à escavação arqueológica com todas as problemáticas inerentes à mesma, a saber: i) registo e compreensão da estratigrafia arqueológica, ii) recolha e registo de artefactos e ecofactos; iii) métodos de escavação apropriados e não apropriados e iv) introdução aos métodos de registo (croquis, desenho, fotografia e topografia). (Figura 7)

- outra enquanto estratégia de aprendizagem e divulgação da prática arqueológica a um público mais vasto, crianças e jovens entre os 4 aos 15 anos constituindo-se como um espaço pedagógico.

Em setembro de 2019, a EPA e a Área Arqueológica do Freixo conceberam um espaço pedagógico que inclui uma exposição e uma oficina para o público que objetiva a ideologia da salvaguarda de uma área arqueológica, monumento nacional, a valorização do profissional em arqueologia e sua ligação à sociedade civil (Mascarenhas et all: 2020). Para além de uma exposição que permite conhecer todos os aspetos diretamente relacionados com a investigação arqueológica de campo, este espaço engloba uma oficina de simulação de escavação arqueológica, inserida na zona habitacional de Tongobriga. Esta oficina, recria três momentos de ocupação do sítio: Idade do Ferro, Período Romano e Época Medieval, incluindo réplicas de estruturas e materiais arqueológicos. Este espaço pedagógico é um upgrade das áreas de escavação portáteis da oficina Arqueólogo por um dia, integrando-se em plena zona habitacional de Tongobriga.

\section{DIDÁTICA DA ARQUEOLOGIA EM "SALA DE AULA"}

O espaço pedagógico sendo uma simulação da escavação arqueológica é o local ideal para a prática experimental e inicial da arqueologia. A simulação da escavação confere seriedade na prática pois reproduz unidades estratigráficas reais e suas relações, permite testar procedimentos ao nível da escavação e registo (escavar, limpar, definir, registar) preparando o técnico para contextos de escavação reais. (Figura 8) Num só local é possível avaliar os alunos a vários módulos técnicos parcelares pois a escavação integra tarefas complexas, exige ao mesmo tempo conhecimentos distintos. A prática com sucesso por parte dos alunos exige conhecimentos técnicos da escavação por camadas, do entendimento da estratigrafia (TIAo7 - Estratigrafia arqueológica), do seu registo (TRAo4 - Desenho de estratigrafia arqueológica), da recolha adequada dos artefactos encontrados em cada camada e da sua posterior análise em fichas de identificação (TIAog - Análise de materiais arqueológicos). E por último, do desenho de materiais (TRAo6, 07, e o8 - Desenho de materiais cerâmicos, objetos e líticos) e da vetorização dos desenhos de campo (TRAog - Tratamento gráfico de desenho arqueológico) em gabinete.

Deste modo, surge naturalmente a ideia de uma avaliação conjunta de dois módulos técnicos TIA o7 Estratigrafia Arqueológica e TIA o9 - Tratamento gráfico de desenho arqueológico, algo compreensível para os arqueólogos. Contudo, uma avaliação modular conjunta não é algo comum pois exige prática colaborativa entre os docentes, como numa escavação entre arqueólogos. Hoje os módulos de diferentes disciplinas ainda são compreendidos pelos docentes como algo estanque e a prática pedagógica é geralmente individual. É também desta necessidade de uma prática docente conjunta que se enquadra a autonomia e a flexibilidade curricular que põe em marcha uma cooperação, em primeiro lugar entre os docentes e em segundo entre os docentes e discentes. O futuro da arqueologia e da educação deve seguir o caminho que aqui apontamos e tentamos realizar. O futuro da arqueologia depende do envolvimento do público em geral e do seu compromisso com o património orientado e fomentado pelos profissionais em arqueologia. Por outro lado, na educação é fundamental a articulação entre disciplinas em prol de um ensino global, integrador e inclusivo. 


\section{BIBLIOGRAFIA}

MASCARENHAS, Ana; SILVA, Júlia; NUNES, Susana; PINTO, Dulcineia; PATRÍCIO, Daniel (2020) - A aprendizagem da arqueologia como agente de desenvolvimento pessoal e social. o estudo de caso da oficina pedagógica em Tongobriga. Comunicação apresentada no TaG Iberico (8ㅁ sessão - No todo es lo que parece: Repensando la educación pública y la divulgación en la Arqueología y en la gestión del Patrimonio de la Península Ibérica. Coord.: Laura Coltofean e Tiago Gil, Lisboa. Faculdade de letras da Universidade de Lisboa. 13-14 de fevereiro de 2020.

Portaria 795/200o, de 20 de setembro - Cria a Escola Profissional de Arqueologia, situada na área arqueológica do Freixo, em Marco de Canaveses - Diário da República n.ำ 218/200o, Série I-B de 2000-09-20.

Portaria 782/2009, de 23 de julho - Regula o Quadro Nacional de Qualificações e define os descritores para a caracterização dos níveis de qualificação nacionais - Diário da República $\mathrm{n} .{ }^{\circ}$ 141/2009, Série I de 2009-07-23.

Catálogo Nacional de Qualificações: http://www.catalogo. anqep.gov.pt/

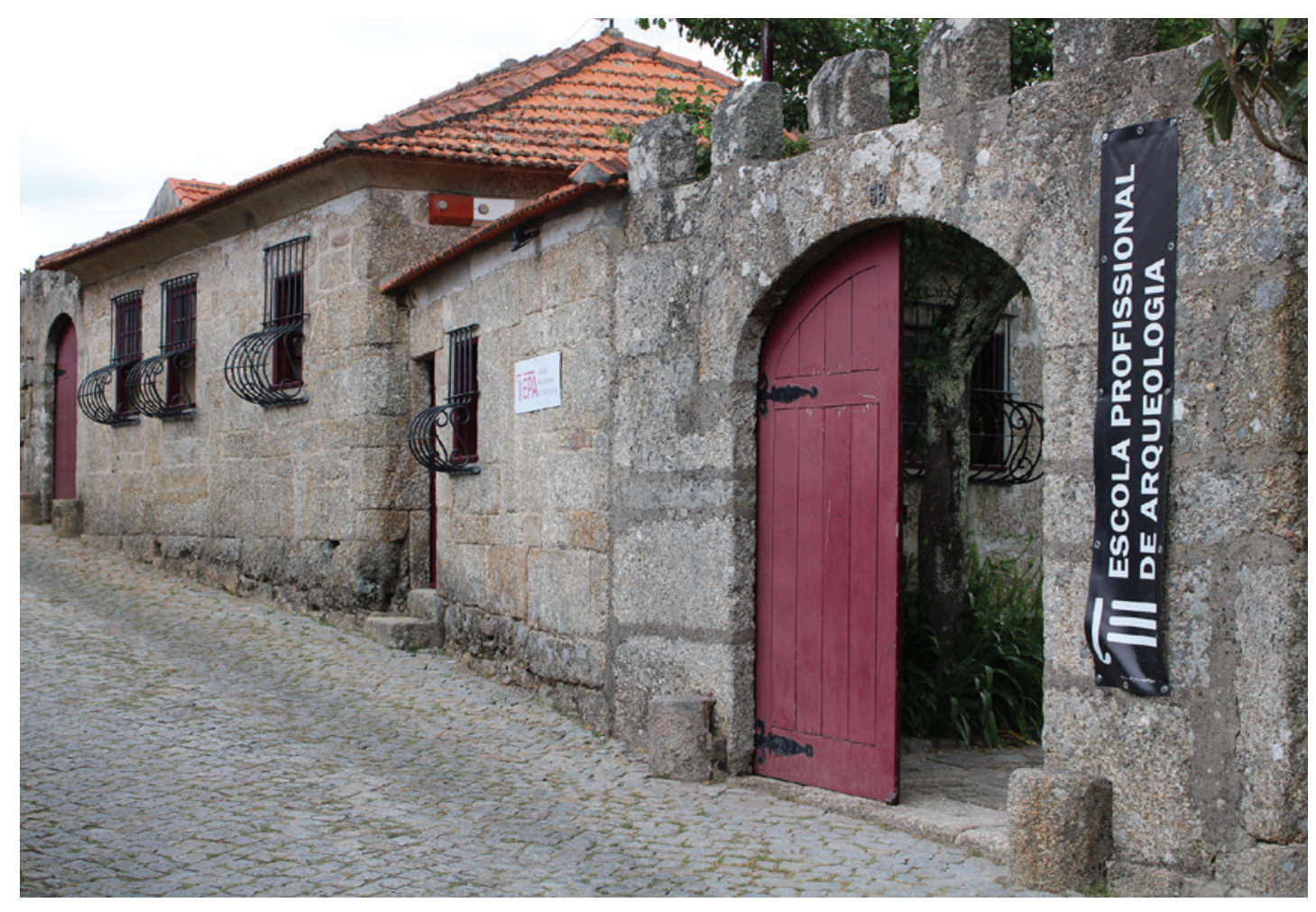

Figura 1 - Escola Profissional de Arqueologia, Freixo. 2020, Escola Profissional de Arqueologia (C. 


\begin{tabular}{|l|l|}
\hline \multicolumn{2}{|l|}{ PLANO MODULAR DO CURSO PROFISSIONAL DE ASSISTENTE DE ARQUEÓLOGO } \\
\hline DISCIPLINAS & TOTAL 3 ANOS \\
\hline Componente Socio Cultural & 1000 horas \\
\hline Português & 320 \\
\hline Inglês & 220 \\
\hline Área de Integração & 220 \\
\hline Tecnologias de Informação e Comunicação & 100 \\
\hline Ed. Física & 140 \\
\hline Componente Científica & 500 horas \\
\hline Física e Química & 200 \\
\hline História da Cultura e das Artes & 200 \\
\hline Matemática & 100 \\
\hline Total de Horas da Componente & 500 \\
\hline Formação Tecnológica - UFCD’s* & 1300 horas \\
\hline Formação em Contexto de Trabalho & 630 horas \\
\hline Total do Plano Curricular & 3430 horas \\
\hline
\end{tabular}

Figura 2 - Plano modular do curso profissional de Assistente de Arqueólogo.

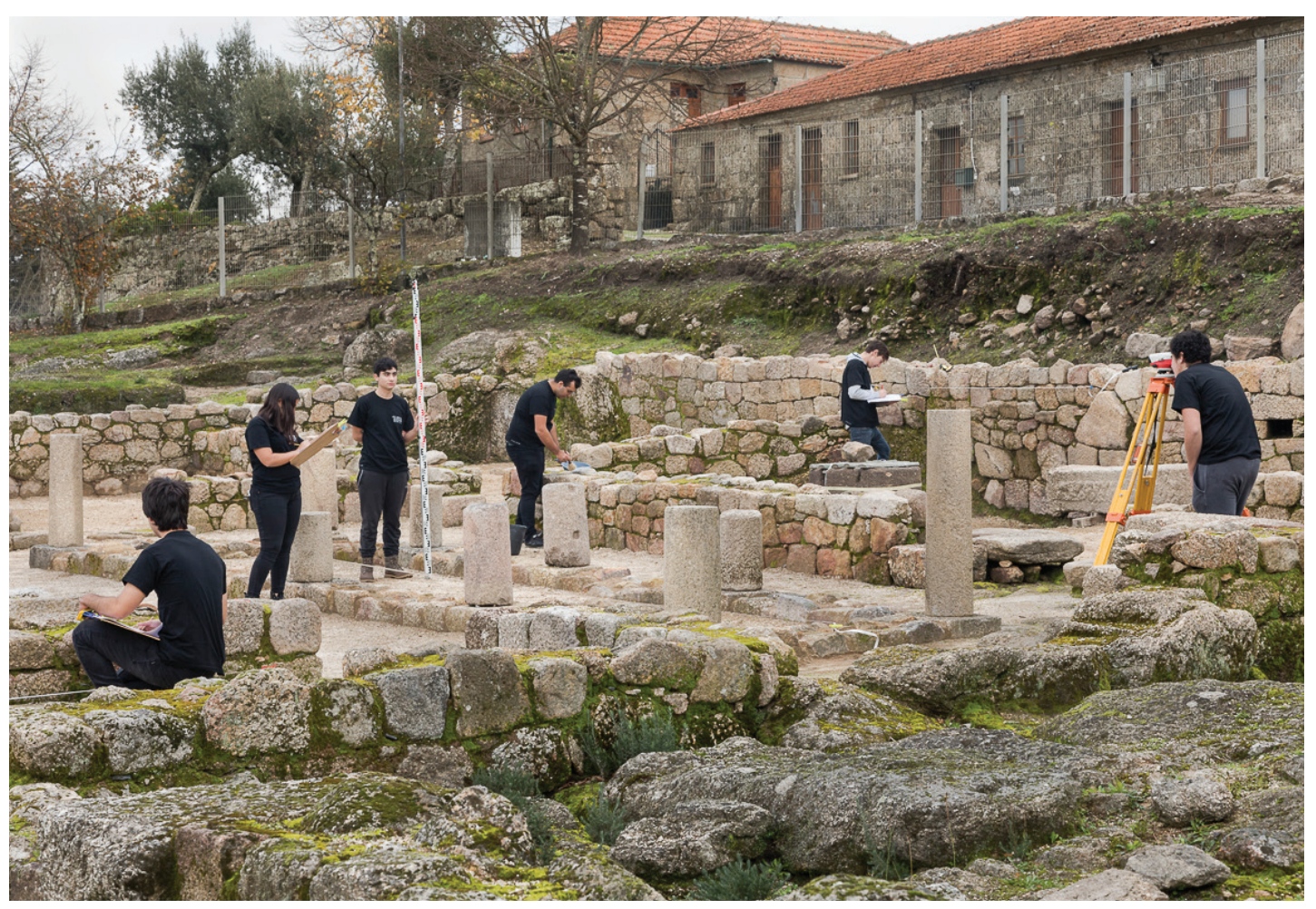

Figura 3 - Momento formativo na Área Habitacional 1 de Tongobriga. 2019, Ricardo Raminhos (C) 


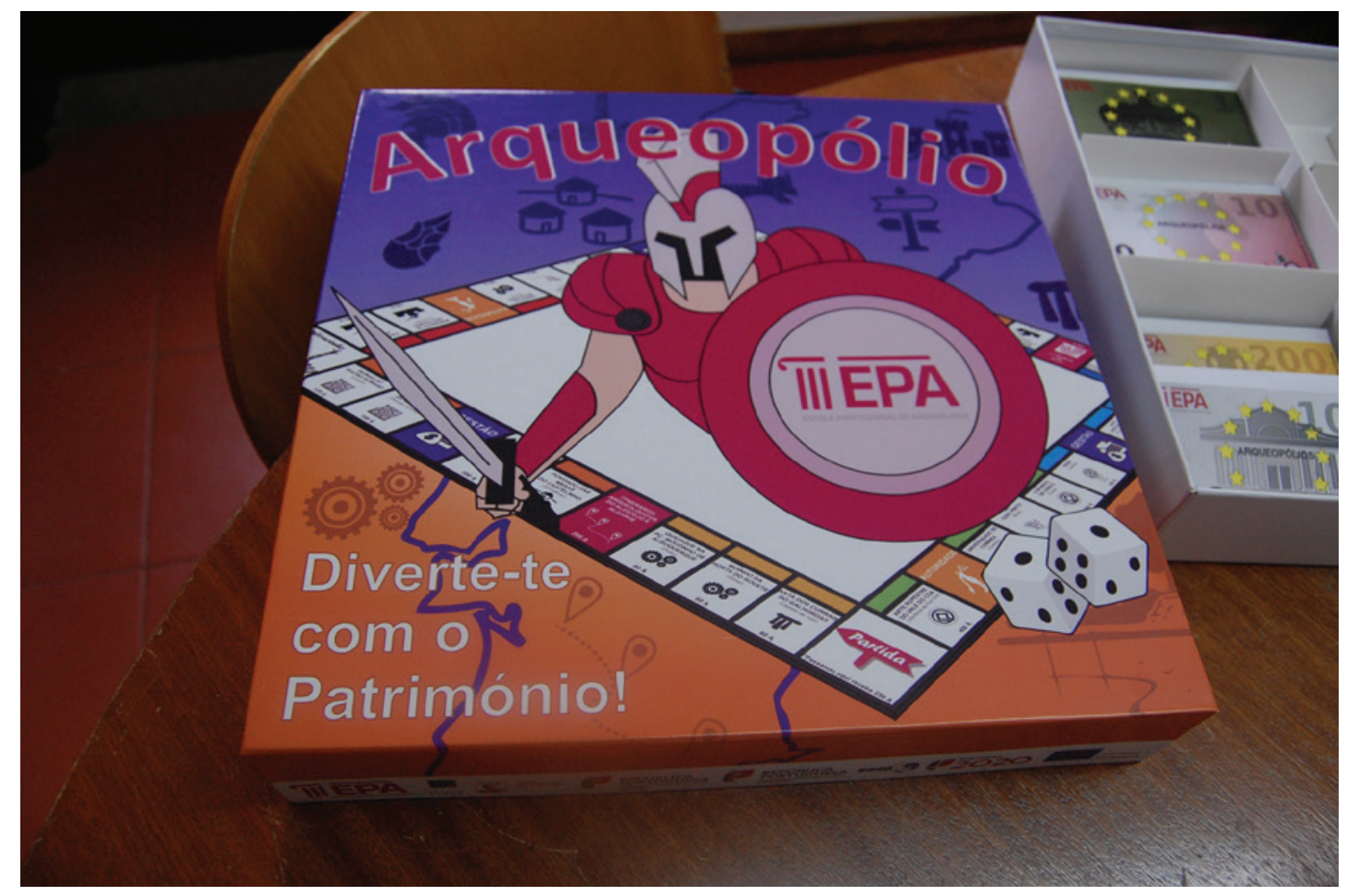

Figura 4 - Jogo de tabuleiro Arqueopólio, desenvolvido no âmbito da 14 a Edição do Prémio Fundação Ilídio Pinho "Ciência na Escola”. 2017, Escola Profissional de Arqueologia (C).

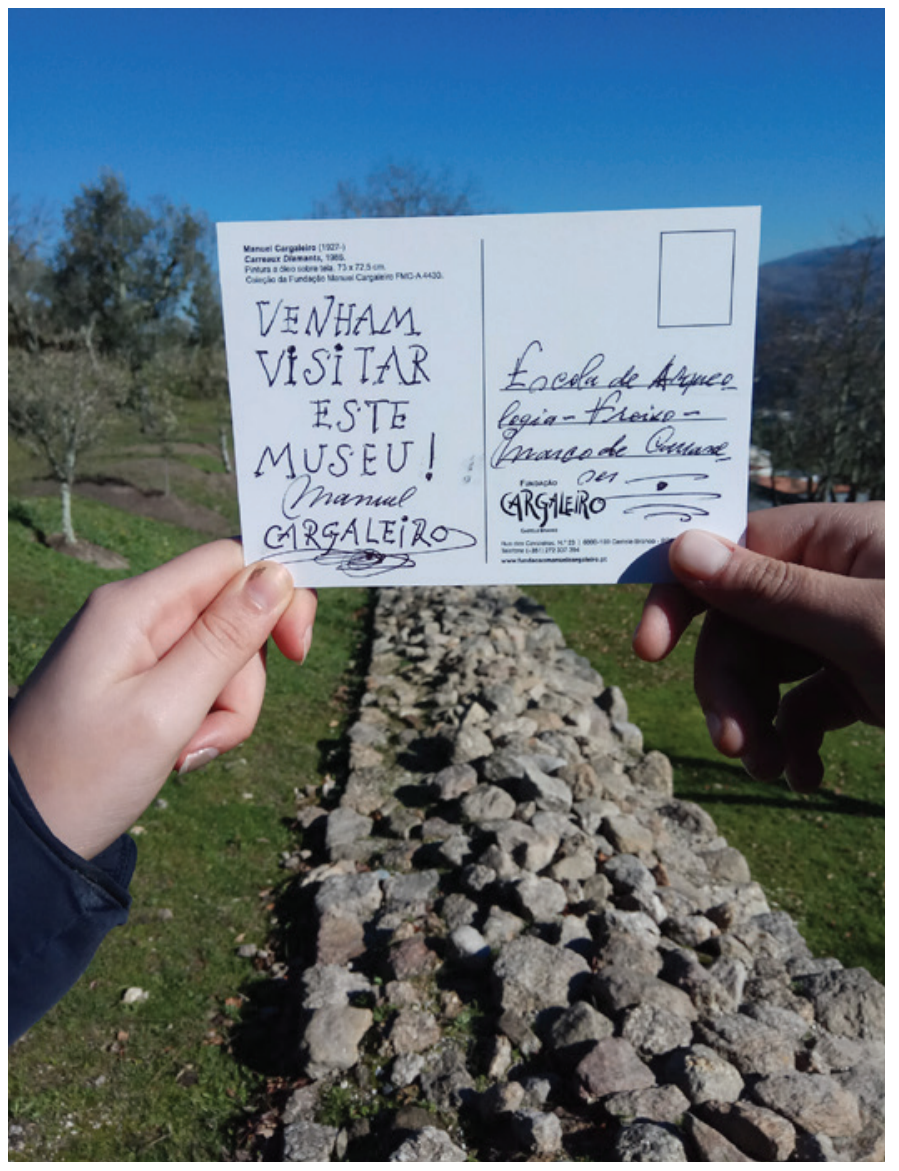

Figura 5-Postal do museu Cargaleiro, enviado pelo próprio artista. 2017, Escola Profissional de Arqueologia (C). 


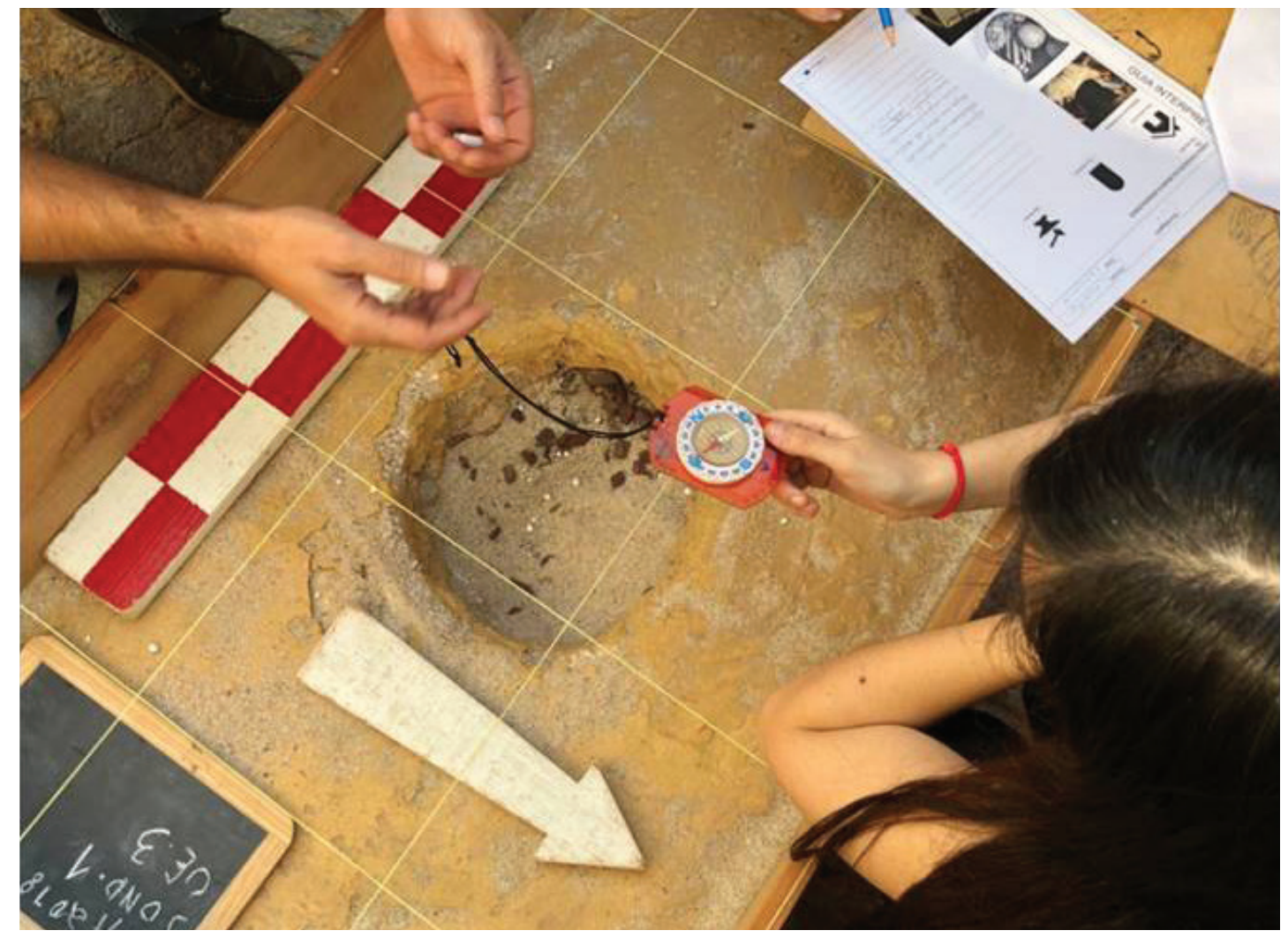

Figura 6 - Oficina Arqueólogo por um dia (2018, Escola Profissional de Arqueologia ( )).

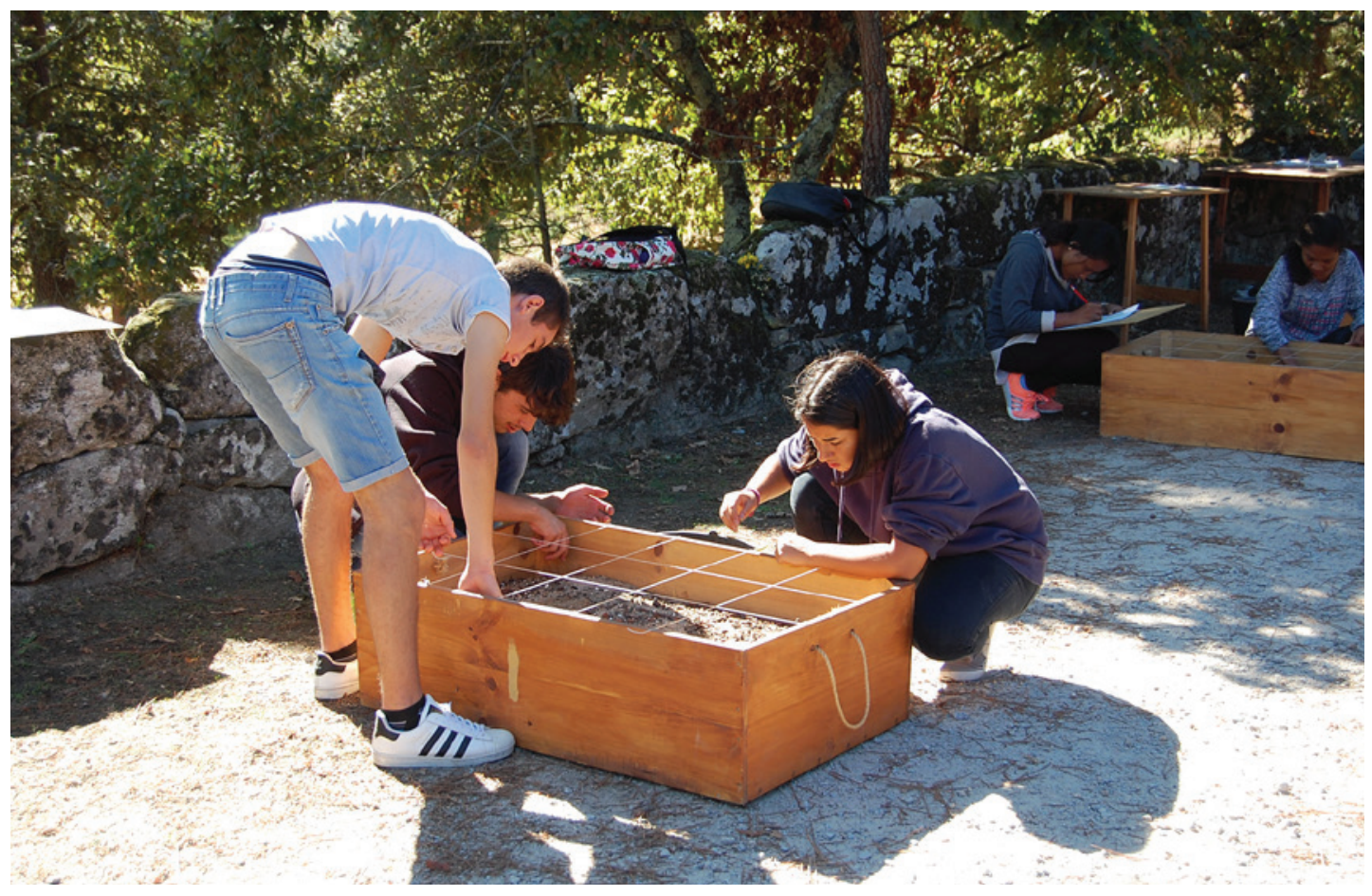

Figura 7 - Simulação de escavação arqueológica por alunos do 1o ano do curso de Assistente de Arqueólogo (2016, Escola Profissional de Arqueologia (C). 


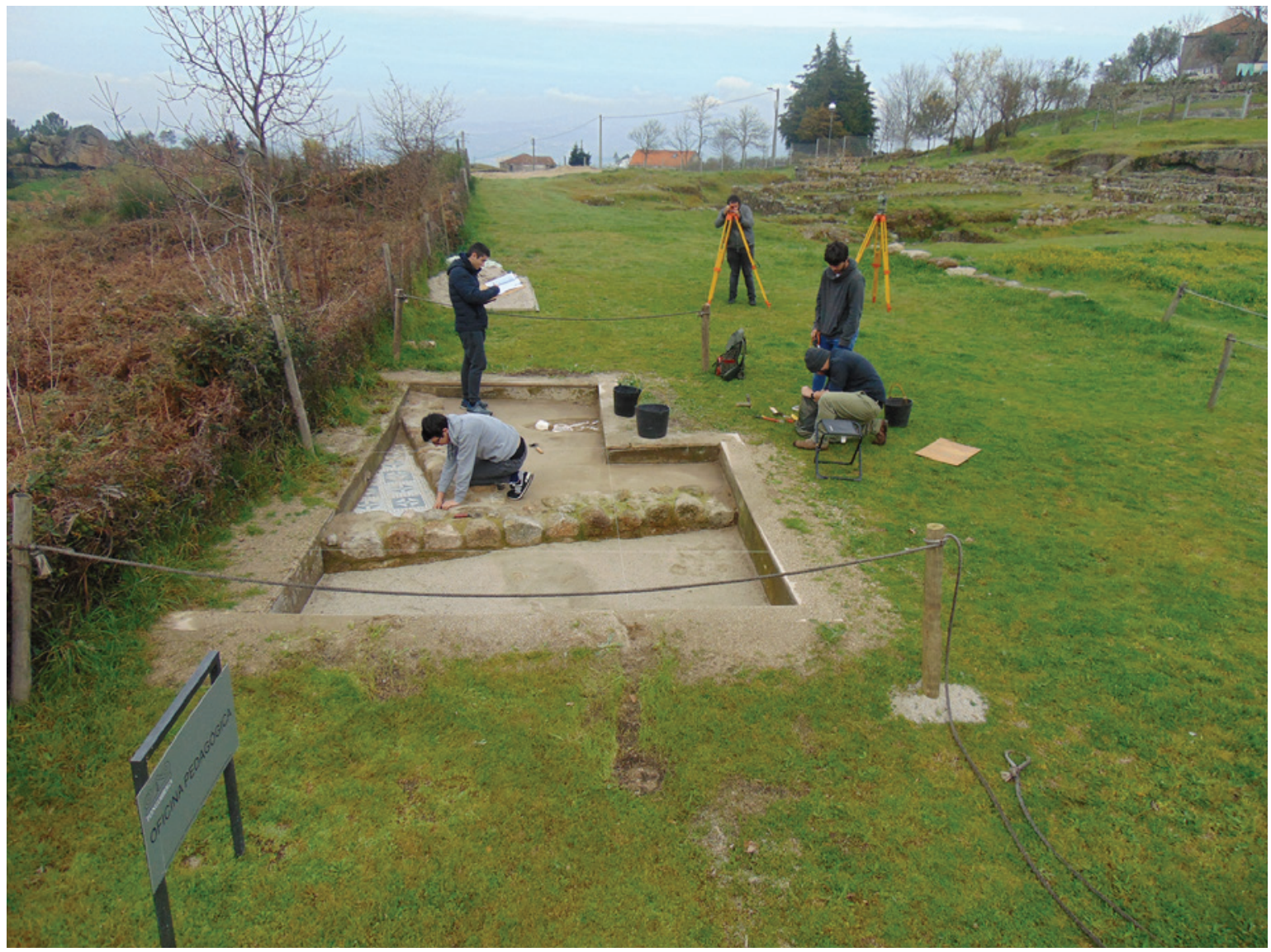

Figura 8 - Oficina de simulação de escavação incluída na Zona Habitacional de Tongobriga. 2019, Escola Profissional de Arqueologia (C). 



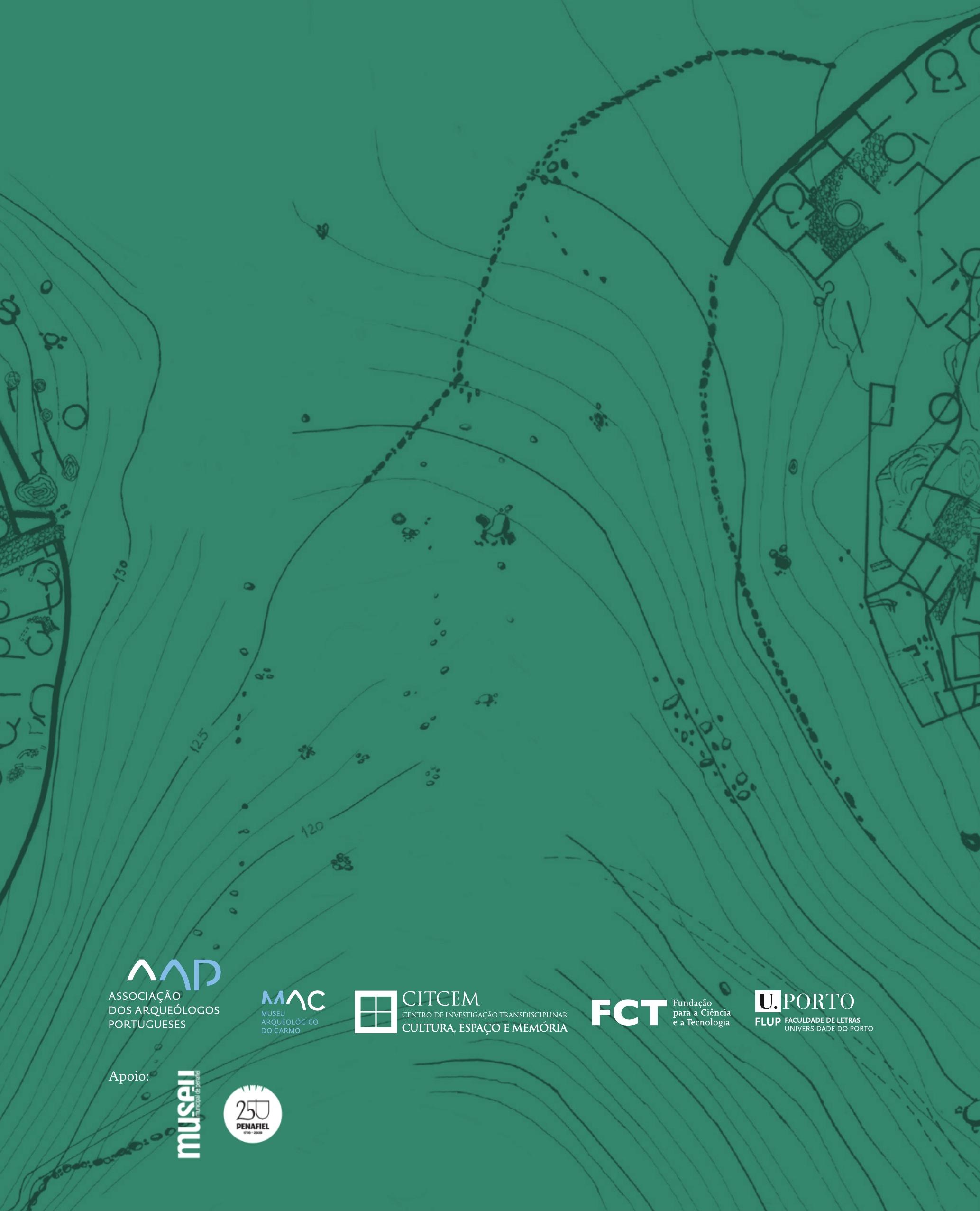

